\title{
TAFSIR AT-TANWIR MUHAMMADIYAH DALAM SOROTAN (Telaah Otoritas Hingga Intertekstualitas Tafsir)
}

\author{
Arivaie Rahman \\ UIN Sunan Kalijaga Yogyakarta \\ arivai.rahman@yahoo.com \\ Sri Erdawati \\ STAI Auliaurrasyidin Tembilahan \\ srierdawati@gmail.com
}

Diterima 24 Juli 2019 | Direview 22 Desember 2019| Diterbitkan 30 Desember 2019

\begin{abstract}
:
This paper reviews Tafsir at-Tanwir (2015) written by the Tarjih dan Tajdid Pimpinan Pusat Mubammadiyah. This research focuses on behind the scenes writing Tafsir at-Tanwir. Besides, it also examines the idea of progressing Qur'anic interpretation, in the form of direction and importance of interpretation, systematic and technical interpretation, and sources of reference of interpretation. This type of research is library research by relying on Tafsir atTanwir as primary data and other literature as secondary sources. Content review using the descriptive-analysis method is supported by historical and hermeneutic approaches. Based on the analysis conducted in this study, several results were obtained: first, the authors of the interpretation are academics and activists of Muhammadiyah, they work at leading Islamic universities in Indonesia, it is very appropriate to call this interpretation as "academic interpretation". This interpretation is not only written by men but also involves the role of women writers. The performance of the interpretations of each team of interpreters varies, some are individual and some are collective, at most interpret 29 verses and at least 1 verse. Secondly, the importance of writing Tafsir at-Tanwir is to mobilize the puritan ideology of Mubammadiyah. In addition, to create responsive interpretations, generate dynamics, and contain the ethos of Mubammadiyah, in the form of an ethos of worship, economic, social, and science. Writing interpretation is very systematic. As a progressive interpretation of the Qur'an, Tafsir at-Tanwir also dares to refer to Arabic and English references, but unfortunately, some still refer to translated books.
\end{abstract}

Keyword: Tafsir at-Tanwir, Mubammadiyah.

\begin{abstract}
Abstrak:
Makalah ini mengulas Tafsir at-Tanwir (2015) yang ditulis oleh Tarjïh dan Tajdid Pimpinan Pusat Muhammadiyah. Penelitian ini berfokus pada penulisan di balik layar Tafsir at-Tanwir. Selain itu, ia juga mengkaji gagasan untuk mengembangkan interpretasi Al-Qur'an, dalam bentuk arahan dan pentingnya interpretasi, interpretasi sistematis dan teknis, dan sumber-sumber referensi interpretasi. Jenis penelitian ini adalah penelitian kepustakaan dengan mengandalkan Tafsir at-Tanwir sebagai data primer dan literatur lain sebagai sumber sekunder. Tinjauan konten menggunakan metode analisis deskriptif didukung oleh pendekatan historis dan hermeneutik. Berdasarkan analisis yang dilakukan dalam penelitian ini, beberapa hasil diperoleh: pertama, para penulis interpretasi adalah akademisi dan aktivis Muhammadiyah, mereka bekerja di universitas-universitas Islam terkemuka di Indonesia, sangat tepat untuk menyebut interpretasi ini sebagai "interpretasi akademik" . Interpretasi ini tidak hanya ditulis oleh pria tetapi juga melibatkan peran penulis wanita. Kinerja penafsiran masing-masing tim juru bahasa berbeda-beda, ada yang bersifat individu dan ada yang bersifat kolektif, paling banyak mengartikan 29 ayat dan setidaknya 1 ayat. Kedua, pentingnya menulis Tafsir at-Tanwir adalah memobilisasi ideologi puritan Muhammadiyah. Selain itu, untuk menciptakan interpretasi responsif, menghasilkan dinamika, dan mengandung etos Muhammadiyah, dalam bentuk etos ibadah, ekonomi, sosial, dan sains. Penafsiran tulisan sangat sistematis. Sebagai interpretasi progresif Alquran, Tafsir at-Tanwir juga berani merujuk pada referensi Arab dan Inggris, tetapi sayangnya, beberapa masib merujuk pada buku-buku yang diterjemabkan.
\end{abstract}

Kata Kunci: Tafsir at-Tanwir, Muhammadiyah. 


\section{Pendahuluan}

Kehadiran Tafsir at-Tanwir, yang diterbitkan oleh Majelis Tarjih dan Tajdid Pimpinan Pusat Muhammadiyah pada Juli 2015, mengisyaratkan seakan ada hembusan angin penyegaran baru dalam tubuh Muhammadiyah. Pasalnya, tafsir-tafsir perintis yang telah ditorehkan oleh tokoh-tokoh pendahulu Muhammadiyah semisal: Hamka (Tafsir al-Azhar), Hasbi Ash-Shiddieqy (Tafsir al-Nur), dan Abdul Malik Ahmad (Tafsir Sinar) tampaknya dianggap tidak mampu memberi sumbangsih banyak terhadap perkembangan zaman dan persoalan umat dewasa ini. Apalagi jika memang berpedoman pada Anggaran Dasar Muhammadiyah, sebagai penggerak dakwah Islam, Amar Makruf Nabi Munkar, berpaham Tajdid (pembaharuan) berlandaskan al-Qur'an dan Sunnah. Tentu kemunculan tafsir yang responsif dan berkemajuan adalah sebuah keniscayaan dan kontribusi yang ditunggu-tunggu oleh warga Muhammadiyah.

Pasca terbitnya Tafsir yang "Pre-Launch Edition" ini, sederet artikel jurnal akademik hingga Skripsi dan Tesis seakan tidak berhenti untuk mengupasnya. Muhammad Syahrul Mubarak menyelesaikan Tesis dengan judul: Kontekstualisasi Surah al-Fatihah dalam Tafsir atTanwir Mubammadiyah (2017). Wajar bila Syahrul hanya membahas tafsir Surah al-Fatihah. Karena perlu diketahui, Tafsir at-Tanwir bukanlah tafsir yang lengkap 30 juz al-Qur'an, meski diduga arah dan proyeknya akan menuju ke sana, tetapi entah kapan akan selesai. Tafsir atTanwir Juz 1 (sama seperti juz 1 dalam al-Qur'an) menafsirakan surah al-Fatihah 1-7, kemudian berlanjut menafsirkan Surah al-Baqarah 1-141. Fokus utama penelitian Syahrul adalah kontekstualitas penafsiran surah al-Fatihah. Meski secara sekilas, ia tidak lepas dari membincang tentang penulis dan metodologi Tafsir at-Tanwir. ${ }^{1}$

Peneliti lain, Syamsul Hidayat (2017) menjelaskan tentang karakteristik, bentuk, metode, corak, sumber, hingga kedudukan Tafsir at-Tanwir di tengah deretan khazanah tafsir alQur'an di Nusantara, bagian yang terakhir inilah yang menjadi fokus kajian Syamsul. ${ }^{2}$

Indal Abror dan M. Nurdin Zuhdi (2018) yang juga meneliti tafsir ini, menyimpulkan bahwa sudah dimaklum dan merupakan komitmen awal gerakan Muhammadiyah menulis tafsir, motifnya tentu mengembalikan umat pada pemurnian ajaran al-Qur'an. Namun metode dan pedekatannya sedikit lebih maju, Tafsir at-Tanwir menawarkan metode Tablilicum-Tematik, seiring mengkombinasikan pendekatan Bayani, Burhani, dan Irfani. Tidak ketinggalan penafsiran yang responsifitas, dinamis, dan menekankan etos terasa benar dalam tafsir Ini. ${ }^{3}$ Penjelasan demikian sebenarnya dapat terbaca dari kata pengantar Tafsir AtTanwir, meski tidak melakukan penelaah mendalam. Berbeda dengan Indal dan Nurdin, Indah Yuliani Jauhari (2019) mengulas sesuatu yang berbeda dan menarik dalam Skripsi-nya, yakni dari sisi aspek Neo-Sufisme." Padahal, Muhammadiyah adalah gerakan puritan. Kendati demikian, ternyata Muhammadiyah tidak seutuhnya menolak tasawuf, akan tetapi mereka memiliki cara pandang tersendiri dan tentunya tidak lepas dari kerangka jargon "Kembali kepada al-Qur'an dan Sunnah". Sebagaimana yang serupa terjadi pada tokoh Hamka yang bersikeras menolak tarekat, tetapi ia tetap menulis Tasawuf Modern. ${ }^{5}$

\footnotetext{
${ }^{1}$ Muhammad Syahrul Mubarak, "KONTEKSTUALISASI SURAH AL- FATIHAH DALAM TAFSIR ATTANWIR MUHAMMADIYAH” (UIN SUNAN KALIJAGA, 2017), http://digilib.uin-suka.ac.id/28442/.

2Syamsul Hidayat, "TAFSIR JAMA'I UNTUK PENCERAHAN UMMAT," Wahana Akademika: Jurnal Studi Islam Dan Sosial 4, no. 2 (January 2, 2018): 245-56, https://doi.org/10.21580/wa.v4i2.2079.

3 Indal Abror and Muhammad Nurdin Zuhdi, “Tafsir Al-Qur'an Berkemajuan: Exploring Methodological Contestation and Contextualization of Tafsir At-Tanwir by Tim Majelis Tarjih dan Tajdid PP Muhammadiyah," ESENSLA: Jurnal Ilmu-Imu Ushuluddin 19, no. 2 (October 23, 2018): 249-77, https://doi.org/10.14421/esensia.v19i2.1347.

${ }^{4}$ Indah Yuliani Jauhari, "Neo-Sufisme Tafsir at-Tanwir QS.al-Fatihah (Karya Tim Penyusun Pimpinan Pusat Majlis Tarjih Dan Tajdid Muhammadiyah)" (undergraduate, UIN Sunan Ampel Surabaya, 2019), http://digilib.uinsby.ac.id/30287/.

${ }^{5}$ Hamka, Tasawuf Modern, (Jakarta: Republika Penerbit, 2015).
} 
Peneliti lain, Muhammad Ridha (2018) mencoba membandingkan Tafsir at-Tanwir (2015) dengan Tafsir Tematik al-Qur'an Tentang Hubungan Sosial Antarumat Beragama (2000), keduanya merupakan dua karya tafsir di lingkungan Muhammadiyah kontemporer. Beberapa aspek yang dibandingkan adalah soal karakteristik dan metodologis, kedua tafsir ini disimpulkan beraliran quasi-objektivis modernis. Mendudukkan al-Qur'an sebagai kitab berparadigma rahmat bagi semesta. Dan etos yang ditanamkan dalam Tafsir at-Tanwir lebih beragam, terdapat etos ibadah, sosial, ekonomi, dan keilmuan. Sementara Tafsir Tematik alQur'an lebih didominasi etos sosial. ${ }^{6}$ Al-Qur'an sebagai rahmat memang selalu diungkap dalam Tafsir at-Tanwir, tetapi tidak tepat bila disebut sebagai paradigma, paling tidak lebih sesuai disebut dengan konsepsi rahmat.

Berdasarkan upaya penjajakan, penelusuran, dan penelaahan terhadap penelitianpenelitian yang telah dilakukan sebelumnya, penulis menilat kajian tentang Tafsir at-Tanwir belum maksimal dan detail. Sehingga mengundang minat penulis untuk melihat kembali tentang kepengarangan dibalik penulisan Tafsir at-Tanwir, berikut pula dengan gagasan tafsir al-Qur'an berkemajuan milik Muhammadiyah. Lengkap dengan tujuan, sistematika, hingga sumber rujukan penafsirannya. Sehingga rumusan masalah yang layak diajukan adalah dua hal berikut: bagaimana belakang layar penulisan Tafsir at-Tanwir Muhammadiyah? Dan bagaimana pula dengan gagasan tafsir al-Qur'an berkemajuan dalam tafsir ini? Dengan menjawab persoalan tersebut, penelitian ini diharapkan mampu memberikan informasi dan pemahaman secara komprehensif tentang identitas, otoritas hingga kinerja penafsiran oleh penulis Tafsir at-Tanwir. Selain itu, kajian ini turut pula mengungkap arah dan kepentingan, sistematika dan teknis cara kerja penafsiran, serta referensi yang menjadi rujukan Tafsir atTanwir.

Penelitian ini tidak lain merupakan riset kepustakaan (library reseach) yang menjadikan Tafsir al-Tanwir Muhammadiyah sebagai sumber primer dan didukung oleh sumber-sumber lain yang dianggap relevan. Metode deskriptif-analisis dan pendekatan historis dan hermeneutika digunakan untuk membaca dan mengeksplorasi jati diri kepengarangan (penulis tafsir) dan teks tafsir yang dihasilkan. Agar penelitian ini runut dan tertata, maka perlu disusun secara sistematis dalam empat sub pembahasan: Bagian pertama, pendahuluan yang berisi latar belakang, rumusan masalah, tujuan penulisan, metode dan pendekatan, dan sistematika pembahasan. Bagian kedua menelisik tentang jati diri penulis Tafsir at-Tanwir untuk melihat identitas, otoritas, kecendikiawanan, keintelektualitasan pengarang tafsir berikut dengan kinerja para penafsir. Bagian ketiga, mengeksplorasi tafsir al-Qur'an berkemajuan Tafsir at-Tanwir dari aspek arah dan kepentingan penulisan, sistematika, teknis penafsiran, dan rujukan penafsiran. Dan terakhir penutup, berupa kesimpulan yang akan menjawab dan merangkum terkait isi artikel sekaligus memberikan saran yang membangun kepada Muhammadiyah dan para akademisi tafsir al-Qur'an.

\section{Belakang Layar Tafsir at-Tanwir Muhammadiyah}

1. Mufasir Muhammadiyah Abad Kedua: Aktifis Plus Akademisi

Para penulis Tafsir at-Tanwir merupakan barisan para akademisi. Semua nama yang tergabung dalan Tim Penulis Tafsir at-Tanwir yang berjumlah 14 orang diletakkan pada halaman belakang dari tafsir ini, semuanya telah menyandang gelar akademik, minimal strata dua (S2). ${ }^{7}$ Benang merah yang dapat ditarik, paling tidak mereka merupakan aktifis Muhammadiyah, yang sebagian besar merupakan dosen di Perguruan Tinggi Negeri maupun Swasta di Indonesia.

Separuh dari penulis Tafsir al-Tanwir telah bergelar Profesor (Guru Besar) dan sebagian lagi menyandang gelar Doktor dan Magister. Tujuh orang profesor yang

${ }^{6}$ MUHAMMAD RIDHA, "TAFSIR KELEMBAGAAN MUHAMMADIYAH (Studi Terhadap Tafsir Tematik Al-Qurean tentang Hubungan Sosial Antarumat Beragama dan Tafsir At-Tanwir)" (masters, UIN Sunan Kalijaga, 2018), http://digilib.uin-suka.ac.id/34019/.

${ }^{7}$ Majelis Tarjih dan Tajdid Pimpinan Pusat Muhammadiyah, Tafsir al-Tanwir, (Yogyakarta: 2015), 491-492. 
tergabung dalam Tim ini adalah: Prof. Sa'ad Abdul Wahid (Guru Besar Hukum Islam UIN Suka Yogyakarta), Prof. Dr. H. Muhammad Zuhri, MA (Guru Besar Tafsir IAIN Salatiga), Prof. Salman Harun (Guru Besar Tafsir UIN Syahid Jakarta), Prof. Muhammad Chirzin (Guru Besar Tafsir UIN Suka Yogyakarta), Prof. Dr. Yunahar Ilyas, Lc., M.Ag (Guru Besar Ulumul Qur'an Universitas Muhammadiyah Yogyakarta), Prof. Dr. H. Syamsul Anwar (Guru Besar Hukum Islam UIN Suka Yogyakarta), dan Prof. Dr. Rusydi A.M (Guru Besar Ilmu Tafsir UIN Imam Bonjol Padang). ${ }^{8}$

Kedudukan penulis Tafsir at-Tanwir yang telah 'bertitel' Profesor ini menguatkan reputasi, otoritas dan kelegalan menafsirkan kalam-kalam Tuhan. Meski secara keilmuan, mereka berasal dari latar disiplin dan konsen keilmuan yang tidak sarupa satu sama lain, tetapi masih dalam satu rumpun Islamic Studies. Mayoritas para Guru Besar tersebut berkiprah di Yogyakarta, sebagai basis lahir dan sentral Organisasi Muhammadiyah sejak lebih dari satu abad lampau. Selebihnya berdomisili di Jakarta, Padang, dan Salatiga. Satu di antaranya merupakan Ketua Majelis Tarjih dan Tajdid Pimpinan Pusat Muhammadiyah, Prof. Dr. H. Syamsul Anwar, M.A., Ia yang memberikan Kata Pengantar tafsir ini, serta berkontribusi menulis tafsir satu ayat dari surah al-Baqarah ayat ke 29.

Selain para Guru Besar, Tafsir at-Tanwir juga ditulis oleh 4 orang doktor dan 3 orang yang telah bergelar magister. Dr. Muhammad Amin, Lc. MA, Dr. Ustadi Hamzah, M.Ag, Dr. Hamim Ilyas, dan Dr. Agung Danarto, M.Ag, Sedangkan mufasir yang masih berpendidikan strata dua (S2) adalah: Dra. Siti Aisyah, M.Ag, Aly Aulia, Lc., M.Hum, dan Moh. Dizkron, Lc., M.Hum. ${ }^{9}$ Tidak ada yang tergabung dalam tim penulis Tafsir al-Tanwir yang berpendidikan sarjana atau starta satu (S1). Jadi, Tafsir at-Tanwir dapat dikatakan sebagai "Tafsir Akademis" tulen, walaupun tafsir ini bukan ditujukan dalam rangka memenuhi tugas akademik, karena semua penulisnya merupakan para akademisi disamping mendarma-baktikan dirinya sebagai aktifis organisasi Muhammadiyah.

\section{Persentase Jenjang Pendidikan / Karir Akademik Penulis Tafsir at-Tanwir Muhammadiyah \\ Magister

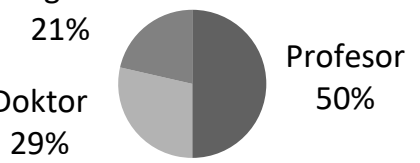

2. Menuju Kesetaraan Gender dalam Menulis Tafsir

Kehadiran seorang mufasir wanita Dra. Siti Aisyiah, M.Ag dalam susunan namanama tim penulis Tafsir at-Tanwir cukup menarik untuk menjadi perhatian. Apakah ini merupakan sebuah kebetulan? atau Muhammadiyah memiliki sayap lain yang ingin digerakkan menuju Muhammadiyah berkemajuan? Pasalnya, mencari ulama perempuan, apalagi yang konsen pada bidang tafsir al-Qur'an di Indonesia diakui sangat sulit. Tanpa menafikkah peran "Aisyiyah" sebagai organisasi otonom kaum wanita dalam tubuh Muhammadiyah. Tetapi, gerakan ini lebih dominan pada bidang pendidikan, kesehatan, dan kesejahteraan sosial, bukan konsen pada pengkajian al-Qur'an.

Mufasir wanita di Indonesia memang tergolong langka. Dari penelitian yang dilakukan Howard M. Federspiel (1996) terhadap 61 literatur Indonesia yang

${ }^{8}$ Majelis Tarjih dan Tajdid Pimpinan Pusat Muhammadiyah, Tafsir al-Tanwir, hlm. 491-492.

${ }^{9}$ Majelis Tarjih dan Tajdid Pimpinan Pusat Muhammadiyah, Tafsir al-Tanwir, hlm. 491-492. 
berhubungan dengan al-Qur'an, hanya menyebutkan satu nama perempuan: Khadijatus Shalihah. ${ }^{10}$ Namun, nama ini tidak menulis tafsir al-Qur'an secara khusus. Ia menulis karya berbau historis berjudul: Perkembangan Seni Baca al-Qur'an dan Qiraat Tujuh di Indonesia (Jakarta: Pustaka Husna, 1983). Karya ini merupakan Skripsi yang telah diterbitkan, sebagai salah satu syarat menyelesaikan kuliah di Institut Ilmu al-Qur'an (IIQ) Jakarta. Tujuan dan sasaran dari karya Khadijatus Shalihah tentu mengarah kepada pembaca yang telah terpelajar, kalangan ilmuwan dan intelektual Muslim. ${ }^{11}$

Selain Khadijatus Shalihah, berdasarkan penelitian Islah Gusmian (2013) terhadap karya-karya tafsir yang terbit pada daswarasa 1990-2000 (sebanyak 24 karya), muncullah sebuah karya yang ditulis oleh seorang penulis wanita, Zaitunah Subhan. ${ }^{12}$ Karya ini berjudul: Tafsir Kebencian: Studi Bias Jender dalam Tafsir (Yogyakarta: LKiS, 1999). Sebuah judul kontroversial, yang pada mulanya merupakan Disertasi doktor di IAIN Syarif Hidayatullah Jakarta, berjudul: Kemitrasejajaran Pria dan Wanita dalam Perspektif Islam. ${ }^{13}$ Zaitulah dapat disebut sebagai mufasir akademis karena penulisan tafsir tematiknya dilatarbelakangi oleh background pendidikan dan tuntutan akademik untuk menyelesaikan jenjang doktoral.

Selebihnya nama-nama perempuan sebagai penulis atau anggota tim penulis tafsir hanya dapat ditemui pada Tafsir al-Qur'an Tematik karya Kementerian Agama dan Lajnah Pentashihan Mushaf al-Qur'an Badan Litbang (2010). Nama-nama tersebut adalah Prof. Dr. Hj. Huzaimah T. Yanggo, MA dan Dr. Sri Mulyati, MA. ${ }^{14}$ Sementara dalam tim penulisan Tafsir Tematik al-Qur'an tentang Hubungan Sosial Antar-umat Beragama karya Majelis Tarjih dan Pengembangan Pemikiran Islam PP Muhammadiyah yang telah terbit tahun 2000 tidak mencantumkan rincian nama tokoh penulis yang tergabung dalam tim tersebut, sehingga tidak dapat terlacak keterlibatan wanita Muhammadiyah dalam penulisan tafsir itu. Diduga, keterlibatan tersebut baru kali ini, dengan alasan ketiadaan tokoh profesional dan beragam pertimbangan lain.

Terlepas dari itu, setelah penulis melakukan penulusuran di dunia cyber (baca: dunia maya), jika tidak keliru karena banyak kesamaan nama, Dra. Siti Aisyiah M.Ag yang dimaksud ini, memang benar merupakan anggota Pimpinan Pusat Aisyiah (priode 2010-2015). ${ }^{15}$ Nama ini juga tercantum dalam keanggotaan Badan Pembina Harian Universitas 'Aisyiah Yogyakarta (priode 2017-2021). Keduanya sama-sama dipimpin oleh Dra. Hj. Siti Noordjanah Djohantini, M.M., M.Si. ${ }^{16}$ Sayangnya, penulis tidak dapat mengekplorasinya lebih jauh, karena keterbatasan data. Meski keterlibatan wanita dalam proyek Tafsir al-Tanwir Muhammadiyah ini tidak terlalu menonjol, yakni hanya satu orang $(7 \%)$ dibanding mufasir laki-laki (93\%), namun tetap harus diapresiasi sebagai langkah awal yang berani. Perlu mendapat dukungan dan menjadi pertimbangan dalam penulisan tafsir al-Qur'an ke depan.

Karena dengan demikian, bias gender patriarkhi dalam menginterpertasi ayat-ayat al-Qur'an dapat ditepis dan diminimalisir. Terutama dalam kasus-kasus yang bertalian erat dengan problematika wanita, seperti: persoalan penciptaan wanita (QS. al-Nisa [4]: 1), kepemimpinan rumah tangga (QS. al-Nisa [4]: 34), Poligami (QS. al-Nisa [4]: 3),

\footnotetext{
${ }^{10}$ Howard M. Federspiel, Kajian al-Qur'an di Indonesia: Dari Mahmud Yunus Hingga Quraish Shibab, (Bandung: Penerbit Mizan, 1996), hlm. 163.

${ }^{11}$ Howard M. Federspiel, Kajian al-Qur'an di Indonesia, hlm. 168-170.

${ }^{12}$ Islah Gusmian, Khazanah Tafsir Indonesia: Dari Hermeneutika Hingga Ideologi, (Yogyakarta: LKis, 2013), hlm. 9597.

${ }^{13}$ Zaitunah Subhan, Tafsir Kebencian: Studi Bias Gender dalam Tafsir al-Qur'an, (Yogyakarta: LKis Pelangi Aksara Yogyakarta, 2016), hlm. Ix.

${ }^{14}$ M. Nurdin Zuhdi, Pasarraya Tafsir Indonesia: Dari Kontestasi Metodologi Hingga Kontekstualisasi, (Yogyakarta: Kaukaba Dipantara, 2014), hlm. 113.

${ }^{15}$ www.kompasiana.com, diakses tanggal 17 Agustus 2019, pukul 14.48 Wib.

${ }^{16}$ www.unisayogya.ac.id, diakses tanggal 17 Agustus 2019, pukul 15.00 Wib.
} 
bagian harta warisan untuk wanita (QS. al-Nisa [4]: 11), kesaksian wanita dalam transaksi muamalah (QS. al-Baqarah [2]: 282), jilbab (QS. al-Ahzab [33]: 59), khimar (QS. al-Nur [24]: 31), menstruasi (QS. al-Baqarah [2]: 222), mengandung dan melahirkan (QS. Fathir [35]: 11, al-Haij [22]: 5, Fushilat [41]: 47), menyusui (QS. alBaqarah [2]: 233), talak terhadap wanita (QS. al-Thalaq [4]: 65), dan masih banyak lagi problem lainnya. Kehadiran dan kontribusi mufasir wanita sangat urgen dalam kasuskasus tersebut.

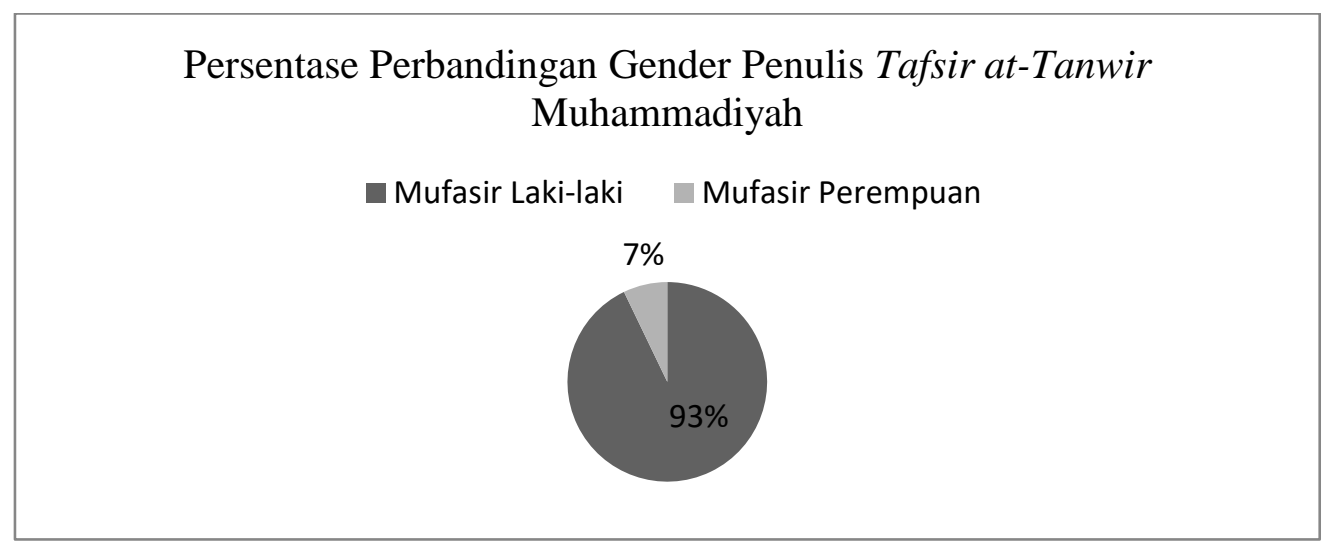

3. Kinerja Mufasir dan Kuantitas Penafsiran

Meski secara formal Tafsir at-Tanwir merupakan tafsir yang disusun secara kolektif, mengatasnamakan Majelis Tarjih dan Tajdid Pimpinan Pusat Muhammadiayah, tetapi dari sisi pembagian tugas penulisannya tidak terjadi demikian. Pada pelaksanaannya, terdapat kelompok kecil dan individual yang menafsirakan ayat tertentu. Realita ini terlihat jelas ketika menafsirkan surah al-Fatihah yang 7 ayat itu. Penafsiran terhadap surah al-Fatihah digarap oleh lima orang: Muhammad Amin, Ustadi Hamzah, Siti Aisyiah, Aly Aulia, dan Moh. Dizkron. Dari lima orang yang tergabung dalam kelompok yang menafsirkan surah al-Fatihah ini, 2 orang diantaranya telah doktoral, sementara 3 sisanya masih magister.

Kemudian yang juga ditafsirkan secara berkelompok adalah penafsiran terhadap surah al-Baqarah 135-141, ditafsirkan oleh tiga orang: Dr. Agung Danarto, Dr. Ustadi Hamzah, dan Aly Aulia, M.Hum. Dan paling sedikit satu kelompok terdiri atas 2 orang, yakni ketika menafsirkan surah al-Baqarah 83-91, oleh Muhammad Amin dan Ustadi Hamzah. Semua penulis yang tergabung dalam kelompok-kelompok tersebut masih menyandang gelar S2 dan S3. Sedangkan para Profesor atau Guru Besar menulis secara individual. Perlakuan berbeda terjadi pada Dr. Hamim Ilyas, ia satu-satunya doktor yang menulis secara individual dan secara kuantitas paling banyak kedua setelah Prof. Muhammad Chirzin, yakni menafsikan sebanyak 23 ayat (Al-Baqarah 8-20 dan 30-39).

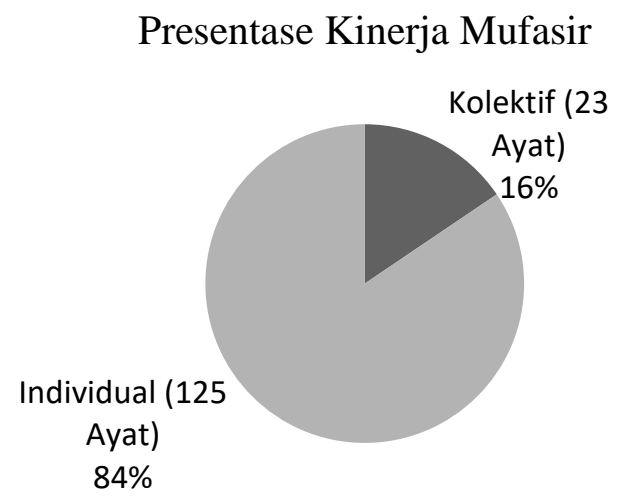


Menarik untuk melihat sosok Hamim Ilyas yang mendapat perlakuan 'anak emas' ini, dugaan awal yang dapat disebut, kemungkinan Hamim Ilyas merupakan seorang yang memiliki posisi tertentu dan jaringan yang kuat di Muhammadiyah, disamping ketekunan menulis, dan mempunyai wawasan keilmuan yang matang, meskipun dirinya belum menjadi Guru Besar (Profesor). Dugaan ini hampir benar, karena Hamim Ilyas merupakan Dosen Syariah dan Ilmu Hukum di UIN Sunan Kalijaga Yogyakarta. Jenjang pendidikan yang ia lalui (S1, S2, dan S3) semuanya di kampus UIN Sunan Kalijaga Yogyakarta. Hamim terlibat aktif dalam menulis jurnal terakreditasi Nasional, misalnya dalam Jurnal Az-Zarqa': Jurnal Hukum Bisnis Islam dan Jurnal Asy-Syir'ah: Jurnal Ilmu Syariah dan Hukum. Ia juga pernah menulis artikel ilmiah berbahasa Inggris, seperti: "The Consept of Sharia in The Quran an its Relevance with Gender Discourse" dalam Indonesian and German Views On The Islamic Legal Discourse on Gender and Civil Right, (Wiesbaden: Harrassowitz Verlag, 2015) dan "Al-Quran and Mirriage Ethics in Islam" dalam Social Ethics in Inter-Relegious Interaction, (Geneva: Globethics.net, 2015). ${ }^{17}$

Bila Hamim Ilyas disandingkan dengan para Guru Besar, maka ada 8 orang yang menulis Tafsir at-Tanwir secara individual. Nama-nama tersebut disusun berdasarkan kuantitas ayat yang mereka tafsirkan: 1). Muhammad Chirzin menafsiran 29 ayat (AlBaqarah 23-24, 67-82, 124-134); 2). Hamim Ilyas menafsirkan 23 ayat (Al-Baqarah 8-20, dan 30-39); 3). Yunahar Ilyas menafsirkan 20 ayat (Al-Baqarah 25-28, 54-59, dan 114123); 4). Rusydi menafsirkan 17 ayat (Al-Baqarah 92-103, dan 109-113); 5). Salman Harun menafsirkan 14 ayat (Al-Baqarah 21-22, 47-53, dan 104-108.); 6). Saad Abdul Wahid menafsirkan 12 ayat (Al-Baqarah 1-5 dan 40-46); 7). Muhammad Zuhri menafsirkan 9 ayat (Al-Baqarah 6-7, dan 60-66), dan paling sedikit 8). Syamsul Anwar yang merupakan Ketua Majelis Tarjih dan Tajdid Pimpinan Pusat Muhamadiyah, ia hanya menafsirkan satu ayat (al-Baqarah 29).

Pembagian kerja penafsiran tersebut disesuaikan dengan konteks ayat atau kelompok ayat-ayat yang memiliki korelasi dan kesatuan tema kecil. Misalnya Muhammad Chirzin menafsirkan al-Baqarah: ayat 23-24, tema pembahasan tersebut diberi judul oleh Chirzin sebagaimana tertulis di daftar isi: Kebenaran dan Keistimewaan al-Qur'an Tidak Terbantahkan (ayat 23-24). Sehingga dengan demikian, masing-masing penafsir tidak akan mendapat porsi ayat yang sama.

\section{Gagasan Tafsir al-Qur'an Berkemajuan}

1. Penulisan Tafsir at-Tanwir: Kepentingan dan Arah

Secara hermeneutis, setiap produk tafsir yang dihasilkan senantiasa berkait berkelindan dengan horison pikir penulisnya. Ada banyak faktor yang mempengaruhi diri pengarang, lingkungan, usia, pendidikan, pekerjaan, ideologi, keilmuan, dan lain-lain semuanya memberi pengaruh. Sebab itu, setiap individu maupun kelompok mufasir dipastikan memiliki kepentingannya masing-masing, meskipun telah diikat oleh visi kolektif institusi dan lembaga. Keberagaman pemikiran dan ketidaksamaan pandangan demikian diakui dalam testimoni Kata Pengantar Tafsir at-Tanwir Muhammadiyah. Sebagaimana dituliskan:

"Banyak kesulitan yang dihadapi dalam penyusunan tafsir ini. Terutama adalah karena banyaknya penulisan dan karena itu beragam cara berfikir masuk ke dalamnya sehingga membuat tim editor menghadapi kesulitan dalam menyelaraskan pemikiran dan pendapat yang beragam itu. Mungkin di sana sini masih dapat dirasakan adanya perbedaan atau keberlainan antar bagian dalam

\footnotetext{
${ }^{17}$ www.uin-suka.ac.id, diakses 18 Agustus 2019, pukul 15.10 Wib.
} 
tafsir ini. Kepada pembaca diharapkan kritik dan masukannya agar edisi percobaan ini dapat diperbaiki dalam edisi final". ${ }^{18}$

Pengakuan di atas dapat diterima karena tafsir ini "baru" sekedar Pre-launch, tafsir yang diterbitkan percobaan sebelum dipublikasikan secara final menjadi tafsir resmi Muhammadiyah. Proyek ini dicanangkan akan selesai dalam kurun waktu 7 tahun, dan akan diterbitkan dalam 30 volume, satu volume berisi 1 juz penafsiran, sesuai urutan yang terdapat dalam mushaf al-Qur'an. ${ }^{19}$ Juz pertama dari Tafsir at-Tanwir ini terdiri atas 492 halaman, maka dapat diperkirakan total keseluruhan halamannya bila telah rampung adalah 14.000 halaman. Sebuah tafsir besar, yang melampaui Tafsir al-Mishbah karya Quraish Shihab yang terdiri atas 15 Volume dan sekitar 10.000 halaman. ${ }^{20}$ Akan tetapi bedanya Quraish Shihab menuliskan tafsirnya secara individual, sementara tafsir Muhammadiyah secara kolektif.

Tradisi menulis tafsir di internal Muhammadiyah bukanlah tradisi seumur jagung. Gagasan dan geliat menulis tafsir telah ada sejak organisasi ini didirikan. Terutama dalam mengusung visi dakwah amar makruf nahi mungkar dan paham tajdid (pembaharuan). Beberapa literatur tafsir yang ditulis oleh ulama Muhammadiyah antara lain berturut-turut: Tafsir Hadi (1936) sebuah tafsir tematik tentang iman, amal, dan akhlak karya Hadikoesuma (w. 1954). Tafsir Hibarna (1936) karya Iskandar Idries (w. 1950-an). Tafsir Langkah Moehammadijah (1939) karya KH. Mas Mansur, tafsir ini menguraikan 12 langkah Muhammadiyah yang berupa petunjuk al-Qur'an dan hadits. Alquran Indonesia (1932) karya Syarikat Kweekschool Muhammadiyah. Dan Tafsir Alquran Djoez Satoe karya Lajnah Oelama Muhammadijah. ${ }^{21}$

Kemudian pasca kemerdekaan, terbit pula Tafsir Hidaajatur-Rahman (1958) karya Moenawar Chalil (w. 1961), menafsirkan surah al-Fatihah dan 2/3 surah al-Baqarah. Tafsir al-Nur (1966) dan al-Bayan karya Hasbi ash-Shiddieqy (w. 1975). Tafsir al-Huda Tafsir Basa Jawi (1979) karya Bakri Syahid (w. 1994), tafsir ini merupakan karya lengkap 30 juz al-Qur'an dalam satu eksamplar. Tafsir al-Azhar karya Buya Hamka (w. 1981), tafsir ini diterbitkan di Jakarta oleh penerbit Tintamas tahun 1992. Kemudian, Tafsir Sinar (1986) karya H. Abdul Malik Ahmad (w. 1993). Dan terakhir sebelum terbitnya Tafsir at-Tanwir (2015), telah terbit sebuah tafsir tematik yang juga merupakan proyek Majelis Tarjih dan Tajdid PP Muhammadiyah, yaitu: Tafsir Tematik al-Qur'an tentang Hubungan Sosial Antarumat Beragama (2010). ${ }^{22}$ Deretan literatur tafsir yang dihasilkan Muhammadiyah merepresentasikan komitmen yang kuat dalam menafsirkan al-Qur'an. Namun memang belum maksimal, lagi pula kebanyakan ditulis secara perorangan, bukan kelompok.

Pada dasarnya, pihak Muhammadiyah mengakui keberadaan tafsir kolektif yang telah disusun oleh Depertemen Agama, tetapi agaknya belum dapat merepresentasikan acuan dan kehendak yang sesuai dengan pemikiran ke-Muhammadiyah-an. Muhammadiyah abad ke-2 tampaknya menginginkan keberadaan literatur tafsir alQur'an yang selaras dengan jati diri Muhammadiyah dan disusun secara kolektif. Alasannya, dengan ditulis secara kolektif akan memperkaya dan memperluas penafsiran yang dihasilkan. Disamping mampu menjawab tanangan zaman yang telah berubah dan kompleksitas problem yang tidak sama dengan yang dihadapi oleh mufasir-mufasir terdahulu.

\footnotetext{
${ }^{18}$ Majelis Tarjih dan Tajdid Pimpinan Pusat Muhammadiyah, Tafsir al-Tanwir, xi.

${ }^{19}$ Abror and Zuhdi, "Tafsir Al-Qur'an Berkemajuan."

${ }^{20}$ M. Quraish Shihab, Tafsir al-Mishbah: Pesan, Kesan, dan Keserasian al-Qur'an, cet. V, (Jakarta: Lentera Hati, 2006).

${ }^{21}$ Siti Mariyatul Kiptiyah, Tafsir Alquran Carakan: Nalar Mubammadiyah dalam Sejarah dan Literatur, Tesis Konsentrasi Hermeneutika al-Qur'an, Prodi Interdisciplinary Islamic Studies, Pascasarjana UIN Sunan Kalijaga Yogyakarta, 2018, 35.

${ }^{22}$ Siti Mariyatul Kiptiyah, Tafsir Alquran Carakan, 36.
} 
Bagi Muhammadiyah, tafsir yang dihasilkan pada abad kedua ini mestilah memiliki karakter lebih maju dari tafsir-tafsir pendahulunya. Pertama, Tafsir at-Tanwir mestilah lebih responsif, menyusun tafsir bukan sekedar mengutip kitab-kitab tafsir, tetapi harus mampu menanggapi persoalan dan fenomena terkini. Kedua, tafsir bukan sekedar dijadikan sesuatu yang normatif, mereka hendak memproduksi tafsir yang mampu menyentuh rohani dan rasionalitas pembaca, sehingga dengan demikian orang akan termotivasi dalam membangun kehidupan yang qur'ani. Ketiga, Tafsir at-Tanwir didesain membangkitkan etos warga Muhammadiyah. Masing-masing etos ini akan disisipkan pada penafsiran ayat-ayat yang relevan dan yang memiliki korelasi kuat. ${ }^{23}$ Ada empat etos yang hendak dikembangkan oleh Tafsir at-Tanwir:

Pertama, etos ibadah. Etos ini perlu dibangkitkan bukan saja ibadah spritual, namun juga ibadah sosial, sebagaimana inspirasi dan spirit tafsir surah al-Maun KH. Ahmad Dahlan. Melalui Tafsir at-Tanwir, kita mendapat kesan ketika menafsirkan surah al-Baqarah [2]: 3 bahwa permasalahan sosial seperti terjadinya korupsi, pencurian, perampokan, pencopetan, dan beragam kejahatan lainnya yang dilakukan oleh orang yang rajin shalat adalah sebab karena shalat yang dilakukan tidak memiliki ruh, tidak khusuk (merendah) dan khudu' (merunduk), meskipun syarat dan rukunnya telah terpenuhi. Tafsir ini juga menekankan ibadah yang berdimensi sosial umpamanya persoalan zakat dan infak. Bila keduanya dikelola dengan baik, kemiskinan dapat dientaskan, sebab orang Muslim yang mampu secara finansial di Indonesia terbilang relatif banyak. Sayangnya mereka lebih ringan untuk melakukan ibadah berdimensi spritual, seperti shalat dan puasa. ${ }^{24}$

Kedua, etos ekonomi termasuk didalamnya etos kerja, hendaknya menjadikan manusia berdisiplin, menghormati waktu, bertanggung jawab, dan lain-lain. Buruknya perekonomian dan pekerjaan salah satunya disebabkan karena belum sepenuhnya bertakwa. Menurut Tafsir at-Tanwir, ketidak mampuan mengatur waktu, ceroboh, tidak disiplin, tidak taat kepada pemimpin, enggan bekerjasama dan memberi manfaat pada orang lain, adalah gambaran tidakmampuan seseorang menghadirkan sikap takwa dalam kesehariannya. $^{25}$ Asas kebangkitan etos ekonomi ini dapat pula dilihat pada pemberdayaan zakat sebagai usaha pemerataan dan pengentasan kemiskinan.

Ketiga, etos sosial. Sebagai organisasi sosial keagamaan tampaknya menjadi urgensitas tersendiri bagi Muhammadiyah mengalu-alukan etos ini. Etos ini dikaitkan dengan infak, shadaqah, zakat, hibah, wakaf dan lain-lain. Prinsipnya menurut mereka adalah kepedulian dan pemberdayaan sosial. Orang-orang lemah harus mendapat kepedulian dan orang-orang kaya mendapat pemberdayaan sikap demikian yang selayaknya dimiliki orang beriman. Konsep penyaluran zakat dan sebagainya menurut Muhammadiyah harus dikelola dengan baik, sehingga tidak langsung habis dikonsumsi oleh penerima zakat, melainkan dalam bentuk modal usaha, beasiswa, jaminan kesehatan, dan kepentingan lain yang lebih luas. ${ }^{26}$

Keempat, etos keilmuan. Semangat keilmuan harus berbanding sejajar dengan semangat keimanan, karena janji Allah untuk mengangkat derajat keduanya. Menurut tafsir ini, tanpa penguasaan terhadap sains dan teknologi umat tidak akan dapat bangkit. Sebab itu banyak penafsiran dalam Tafsir at-Tanwir membincang dan merujuk berbagai persepektif sains: astronomi, fisika, biologi, bahkan tafsir ini tidak segan memberi beberapa judul sub penafsiran yang terkait dengan memakai istilah-istilah sains modern, seperti: istilah kosmologi ketika menafsiran al-Baqarah [2]: 29 dan istilah antropologi ketika menafsirkan surah al-Baqarah [2]: 30-39. Perspektif Kosmologi dalam tafsir ini

${ }^{23}$ Majelis Tarjih dan Tajdid Pimpinan Pusat Muhammadiyah, Tafsir al-Tanwir, viii.

${ }^{24}$ Majelis Tarjih dan Tajdid Pimpinan Pusat Muhammadiyah, Tafsir al-Tanwir, 97-101.

${ }^{25}$ Majelis Tarjih dan Tajdid Pimpinan Pusat Muhammadiyah, Tafsir al-Tanwir, 118.

${ }^{26}$ Majelis Tarjih dan Tajdid Pimpinan Pusat Muhammadiyah, Tafsir al-Tanwir, 104-106. 
dipakai untuk menjelaskan tentang penciptaan Allah terhadap alam raya, langit dan bumi. Penciptaan tersebut menggunakan kata 'khalaqa' maknanya Allah membuat sesuatu yang belum ada contohnya. Dalam teologi, teori ini disebut creatio ex nibilo, merancang sesuatu yang semulanya tidak ada. ${ }^{27}$ Sementara ilmu antropologi dipakai untuk menafsirkan tentang penciptaan manusia awal dan tujuan dari diciptakannya manusia di muka bumi. ${ }^{28}$

2. Sistematika dan Teknis Penafsiran

Tafsir at-Tanwir Muhammadiyah disusun sangat sistematis, laiknya sebuah karya tulis ilmiah. Terdapat kata pengantar, pedoman transletarasi, daftar isi, dan diakhiri dengan daftar pustaka serta dilengkapi dengan daftar nama penulis tafsir. Penafsiran terhadap surah al-Fatihah dibagi menjadi empat bagian dengan huruf kapital: A. Pendahuluan, B. Pandangan Hidup, C. Jalan Hidup, dan D. Penutup. Bagian pendahuluan sifatnya hanya sebagai pengantar, bagian ini menguraikan kedudukan surah al-Fatihah, nama lain dari al-Fatihah, jumlah ayat, hukum membaca basmalah, dan mulai mengarahkan tentang kandungan pokok dari surah al-Fatihah. Bagian penafsiran secara fokus terletak dalam point B (menafsirakan ayat 1-4) dan point $C$ (menafsirkan ayat 5-7). Sementara point D berisi kesimpulan dan pelajaran yang bisa dipetik dan dipraktekkan dalam keseharian setelah menelaah surah al-Fatihah. Bagian penutup ini sekitar dua halaman lebih dan diujungnya disudahi dengan kata "wallahu a'lam".

Sedangkan penafsiran terhadap surah al-Baqarah ayat 1-141, terdiri atas 2 bagian. Sebelum bagian pertama, didahului oleh pendahuluan yang hanya menghabiskan 2 halaman. Kemudian masuk bagian pertama "al-Qur'an Sebagai Petunjuk (ayat 1-39)", yang terdiri atas empat bab: Bab I, Sikap Manusia Terhadap Petunjuk al-Qur'an; Bab II, penerimaan dan Penolakan Petunjuk al-Qur'an; Bab III, Kosmologi dan Pandangan Dunia yang Afirmatif; dan Bab IV, Antropologi: Konsepsi Penciptaan Manusia untuk Meraih Kejayaan. Bagian pertama ini menghabiskan 135 halaman (hlm. 87-222).

Kemudian berlanjut ke bagian kedua "Dakwah Kepada Bani Israil dan Pelajaran dari Kisah Mereka (ayat 40-103)", terdiri atas lima bab: Bab I, Petunjuk kepada Bani Israil dan Balasan Terhadap Pengingkaran Mereka; Bab II, Anugrah Tuhan Kepada Bani Israil dan Sikap Bandel Mereka; Bab III, Respons al-Qur'an Terhadap Bani Israil; Bab IV, Bimbingan Bagi Orang Beriman Sehubungan Dengan Prilaku Orang-orang Kafir, Bab V, Perujukan Kepada Millah Ibrahim. Bagian kedua ini menghabiskan 261 halaman (hlm. 223-484).

Sedangkan secara teknis, penafsiran dalam Tafsir at-Tanwir Muhammadiyah dapat diuraikan sebagai berikut: Pertama, menyebutkan nama surah yang akan ditafsirkan. Penamaan surah diulang dua kali, dengan huruf Roman-Latin, kemudian dibawahnya dengan tulisan Arab. Misalnya: Surah al-Fatihah, dibawahnya dengan aksara Arab tanpa harakat (سورة الفاتحة). ${ }^{29}$ Namun kejanggalan terjadi pada penamaan Surah al-Baqarah. Di bawah nama surah ini tidak ditulis dengan tulisan "سورة البقرة" melainkan tetap Surah alFatihah. ${ }^{30}$ Tampaknya telah terjadi kekeliruan yang telah dilakukan oleh tim editor (Muhammad Amin, Ustadi Hamzah, Siti Aisyah, Aly Aulia, dan Mohammad Dzikron), untuk tidak mengatakan bahwa itu adalah hasil copy-paste (copas).

Kedua, menuliskan ayat yang hendak ditafsirkan. Dalam kasus surah al-Fatihah, karena tergolong surah pendek, semua ayat lengkap dituliskan 1-7. Ayat 1, basmalah diletakkan dalam posisi center (rata tengah), sementara ayat 2-7 diletakkan dibawahnya

\footnotetext{
${ }^{27}$ Majelis Tarjih dan Tajdid Pimpinan Pusat Muhammadiyah, Tafsir al-Tanwir, 188-190.

${ }^{28}$ Majelis Tarjih dan Tajdid Pimpinan Pusat Muhammadiyah, Tafsir al-Tanwir, 197-215.

${ }^{29}$ Lihat: Majelis Tarjih dan Tajdid Pimpinan Pusat Muhammadiyah, Tafsir al-Tanwir, 1.

${ }^{30}$ Lihat: Majelis Tarjih dan Tajdid Pimpinan Pusat Muhammadiyah, Tafsir al-Tanwir, 85.
} 
dalam posisi justify (rata kiri-kanan). Font huruf Arab lebih besar dari huruf latin, dituliskan dari kanan ke kiri, dan dibubuhi nomor yang dilingkari pada tiap ujung ayat. ${ }^{31}$

Ketiga, menuliskan terjemahan ayat. Pada terjemahan didahului nomor ayat yang diberi dua tanda kurung, baru kemudian terjemahan untuk tiap-tiap ayat. Penerjemahan dalam Tafsir at-Tanwir mengalami sedikit-banyak perbedaan dengan terjemahan Kementerian Agama. Contohnya: pada terjemahan ayat basmalah, al-Qur'an terjemahan Kementerian Agama biasa menulis: "Dengan menyebut nama Allah yang Maha Pemurah lagi Maha Penyayang" sementara terjemahan Tafsir at-Tanwir ditulis: "Dengan nama Allah yang Maha Pengasih lagi Maha Penyayang". ${ }^{32}$ Perbedaannya terletak pada tambahan kata "menyebut", sementara dalam Tafsir at-Tanwir tidak dijumpai, dan lebih memilih kata "Pengasih" sebagai terjemahan kata "al-Rahman" daripada kata "Pemurah".

Keempat, memberikan pendahuluan. Pada penafsiran surah al-Baqarah, bagian ini diletakkan pada urutan ke dua. ${ }^{33}$ Pendahuluan berisi penjelasan tentang asal-usul nama surah yang berkaitan, priode turunnya surah (makkiyah atau madaniyah), keutamaan surah, jumlah ayat, dan kandungan pokok surah. Pada pendahuluan surah al-Fatihah, tampaknya pihak Muhammadiyah perlu mendudukan tentang jumlah ayat dan kedudukan membaca basmalah. Mungkin mengingat persoalan ini sering menjadi polemik turun-temurun di tanah air, disamping kesempatan untuk menetapkan sikap dan mengukuhkan identitas sebagai Islam Reformis. Dalam Tafsir at-Tanwir, Muhammadiyah menarjih pendapat yang paling kuat bahwa al-Fatihah terdiri atas tujuh ayat, dan basmalah adalah ayat pertama. Sedangkan persoalan hukum membaca basmalah ketika shalat adalah wajib. Lagi-lagi Muhammadiyah memilih pendapat terkuat. Basmalah boleh di baca secara Jahr (nyaring) dan boleh secara Sirr (lirih). Ketika menjelaskan persoalan ini Tafsir at-Tanwir merujuk buku Tanya Jawab Agama (1998) yang diterbitkan oleh Tim PP Muhammadiyah. ${ }^{34}$

Bagian menarik ketika membarikan pendahuluan surah al-Baqarah, terdapat uraian munasabah (korelasi) antar surah yang tidak penulis temui pada penafsiran surah al-Fatihah. ${ }^{35}$ Munasabah tersebut antara surah al-Baqarah dengan surah sebelumnya, surah al-Fatihah. Menurut tim penulis Tafsir at-Tanwir, keserasian itu dapat disesuaikan bila menariknya dari ayat ke empat surah al-Fatihah yang berisi tentang permohonan agar diberikan petunjuk ke jalan yang lurus. Al-Baqarah menyambung dan menerangkan permohonan tersebut, bahwa al-Qur'an tidak terdapat keraguan di dalamnya dan merupakan petunjuk bagi orang-orang yang takwa. Ditambah lagi alasan bahwa surahsurah setelah al-Fatihah merupakan rincian dari hal-hal pokok yang terkandung didalamnya. Penjelasan tentang ini mereka kutip dari imam al-Suyuthi, melalui kitabnya Tanasuq al-Durar fi Tanasub al-Suwar. ${ }^{36}$ Sejatinya penjelasan tentang munasabah terbilang penting, sebab dengan demikian al-Qur'an menjadi serasi dan keteraturan susunannya menjadi bukti mukjizat.

Kelima, menafsirkan dengan pendekatan kebahasaan. Misalnya, ketika menafsirkan kata al-Rahman dan al-Rabim. Tafsir at-Tanwir merujuk kepada pakar mufradat al-Qur'an,

\footnotetext{
${ }^{31}$ Lihat: Majelis Tarjih dan Tajdid Pimpinan Pusat Muhammadiyah, Tafsir al-Tanwir, 1.

32Lihat: Majelis Tarjih dan Tajdid Pimpinan Pusat Muhammadiyah, Tafsir al-Tanwir, 1.

33Lihat: Majelis Tarjih dan Tajdid Pimpinan Pusat Muhammadiyah, Tafsir al-Tanwir, 85.

${ }^{34}$ Majelis Tarjih dan Tajdid Pimpinan Pusat Muhammadiyah, Tafsir al-Tanwir, 5-6.

${ }^{35}$ Munasabah dalam studi al-Qur'an setidaknya terbagi atas tujuh macam: 1). Munasabah antar surah dengan surah sebelumnya; 2). Munasabah antar nama surah dan tujuan turunnya; 3). Munasabah antar bagian suatu ayat; 4). Munasabah antar ayat yang letaknya berdampingan; 5) Munasabah antar suatu kelompok ayat dan kelompok ayat di sampingnya; 6). Munasabah antar fashilah (pemisah) dan isi ayat; 7). Munasabah antar awal surah dengan akhir surah yang sama; 8) Munasabah antar penutup suatu surah dengan awal surah berikutnya. Rosihon Anwar, Ulum al-Qur'an, (Bandung: CV. Pustaka Setia, 2015), 84-95.

${ }^{36}$ Majelis Tarjih dan Tajdid Pimpinan Pusat Muhammadiyah, Tafsir al-Tanwir, hlm. 86.
} 
Raghib al-Ashfahani. Tafsir ini juga menjelaskan tentang timbangan (wazan) dari kata (رحمان) rahmân yang sama dengan pola (فعلان) fa'lân, dan katan (رحيم) rahîm sama dengan pola (فعيل) fa'̂ेl. Keduanya memiliki makna yang tidak sama, yang pertama "rahman" sifatnya tidak permanen, sementara "rahim" sifatnya permanen. ${ }^{37}$ Menafsirkan al-Qur'an menggunakan pendekatan lughawiyah (kebahasaan) semacam ini tidak dapat diabaikan. Al-Qur'an turun menggunakan bahasa Arab yang kaya dan multi makna. Sedikit mengalami perobahan huruf, bahkan sekedar harakat akan mengubah pemaknaan yang berbeda dan jauh dari maksud yang diinginkan.

Keenam, menafsirkan al-Qur'an dengan al-Qur'an. Cara ini merupakan penafsiran yang terbilang klasik namun memiliki kedudukan utama dan pertama untuk dilakukan oleh seorang mufasir. Teorinya menyebutkan: "Sebagian ayat al-Qur'an itu menfasirkan sebagian ayat yang lain". Berpatokan dengan ini, tidak heran bila hanya untuk menafsirkan kata "al-rahman" dan "al-rahim" ada sekian ayat yang dikutip oleh Tafsir atTanwir. Di antaranya adalah: surah al-A'raf [7]: 156, al-Qashash [28]: 86), al-Dukhan [44]: 6, dan al-Anbiya [21]: 107. Rentetan ayat-ayat tersebut memiliki kandungan kata "al-rahmah". Berdasarkan inspirasi kata ini pula Tafsir at-Tanwir seolah kekeh dan bersemangat mendemonstrasikan kedudukan al-Qur'an sebagai kitab rahmat. Bahkan telah dialu-alukan dalam kata pengantar tafsir ini.

Ketujuh, menafsirkan dengan pendekatan filosofis. Penafsiran secara filosofis ditemukan ketika menafsirkan kata "rabb". Bahkan Tafsir at-Tanwir merujuk tokoh Filsuf Muslim, al-Kindi melalui tulisan Peter Adamson. Terkait kata "rabb" yang dapat berarti pencipta, pemelihara, pengatur, dan yang semakna dengannya. Masuk akal, tidak mungkin adanya sesuatu tanpa ada yang meng-ada-kannya. Dan yang paling awal mengada-kan sesuatu itulah Allah -bagi orang muslim- atau ilah al-ula (pencipta pertama) yang mencipta alam semesta.

Kedelapan, menafsirkan dengan pendekatan sains. Nuansa sains lebih kental dalam Tafsir at-Tanwir. Selalu saja ayat-ayat al-Qur'an diterangkan melalui sudut pandang ilmu pengetahuan: biologi, fisika, astronomi, dan lainnya. Bahkan tafsir ini membantah teori evolusi dengan sederet ayat-ayat al-Qur'an, seolah sedang terjadi gempuran hebat teologis berhadapan sains. Menurut tafsir ini, manusia sebagai khalifah adalah makhluk yang terakhir diciptakan setelah semua perlengkapan yang disediakan untuknya telah siap. Begitu pula dengan penciptaannya secara khusus. Bukan berasal dari proses evolutif dari bentuk yang rendah menuju sempurna. Tetapi, pada sisi lain, tafsir ini cukup kontoversial ketika membicarakan soal Adam. Adam diyakini sebagai manusia pertama yang paling sempurna, paling cerdas, dan paling berbudaya. Namun, mereka menganggap Adam memiliki asal-usul orang tua (sebagaimana Isa, QS. ali Imran [3]: 59), hanya saja leluhurnya itu belum sampai pada derajat kecerdasan sempurna sehingga tidak dijadikan khalifah fi al-ardh. Tentang siapa leluhur Adam itu, al-Qur'an tidak menginformasikannya. ${ }^{38}$

Kesembilan, menafsirkan al-Qur'an dengan hadits. Meski kedudukan hadits sebagai penafsir al-Qur'an menempati posisi teratas dalam metode dan pendekatan tafsir klasik, namun tidak terjadi demikian dengan Tafsir al-Tanwir Muhammadiyah. Hadits kurang mendapat perhatian istimewa. Dua buah hadits riwayat al-Bukhari dijadikan sebagai landasan menyatakan keutamaan dan hukum membaca al-Fatihah. ${ }^{39}$ Selebihnya hanya tidak terlalu masif, dalam penafsiran surah al-Fatihah ditemukan hadits tentang amalan yang terputus setelah meninggal dunia (hlm. 45); kondisi di alam barzakh (hlm. 46 dan

${ }^{37}$ Majelis Tarjih dan Tajdid Pimpinan Pusat Muhammadiyah, Tafsir al-Tanwir, hlm. 10.

38 Majelis Tarjih dan Tajdid Pimpinan Pusat Muhammadiyah, Tafsir al-Tanwir, 18-29.

${ }^{39}$ Majelis Tarjih dan Tajdid Pimpinan Pusat Muhammadiyah, Tafsir al-Tanwir, 2-3. 
47); dan terakhir tentang menjaga sikap demi menggapai kemaslahatan bersama (hlm. 78).

Kesepuluh, menafsirkan al-Qur'an dengan Qira'at. Penjelasan ragam baca al-Qur'an dalam Tafsir at-Tanwir dijumpai ketika menafsirkan ayat: "maliki yaum al-din". Surah alFatihah ayat keempat. Huruf 'mim' pada kata: "malik" bisa dibaca panjang dan bisa dibaca pendek. Kedua varian ini memiliki konsekuensi pemaknaan yang berbeda, namun masih bisa ditolerir, sebab merupakan bagian dari qira'at sab'ah yang shabih dan mutawatirah. Dalam kasus ini Tafsir at-Tanwir mengutip penjelasan Ibn Katsir (w.774 $\mathrm{H}){ }^{40}$

Kesebelas, menafsirkan al-Qur'an sejalur dengan ideologi ke-Muhammadiyah-an. Tidak dapat dipungkiri, ide pemurnian Islam terjadi dalam Tafsir at-Tanwir. Hal ini tergambar pada saat menafsirkan surah al-Fatihah ayat ke-lima, persoalan ibadah. Disamping merujuk pendapat al-Zamakhsyari (w. $1144 \mathrm{M}$ ), tafsir ini merujuk lebih lanjut definisi 'ibadah' yang dibuat oleh Rasyid Ridha (w. 1935 M) seorang modernis muslim, penerus al-Afghani dan Abduh. Penekanan trilogi tauhid yang dianut Muhammadiyah, juga terlihat dengan pernyataan bahwa ibadah merupakan perwujudan dari Tauhid Uluhiyah. Tafsir ini juga secara secara tidak langsung sedang menyindir lawan-lawan ideologisnya, misalnya terkait memohon pertolongan kepada kuburan meskipun kubur orang shaleh dianggap sesat dan syirik. Tafsir at-Tanwir juga menekankan tentang pentingnya pemahaman kembali terhadap Masail Khams (masalah lima) yang telah dirumuskan dalam Himpunan Putusan Tarjib. ${ }^{41}$

Kedua belas, memberikan penutup yang isinya berupa kesimpulan dan rangkuman dari uraian tafsir. Dua belas teknis dan praktek penafsiran ini berdasarkan penelaahan terhadap tafsir surah al-Fatihah dalam Tafsir at-Tanwir. Bisa saja berbeda dengan yang ditemui dalam penafsiran surah al-Baqarah. Namun paling tidak, kecendrungan, nuansa, dan pendekatan Tafsir at-Tanwir telah terepresentasikan melalui penjelasan di atas.

3. Sumber Rujukan Tafsir at-Tanwir

Ada 66 buah karya yang dirujuk oleh Tim Penulis untuk menulis Tafsir at-Tanwir. Karya-karya yang dijadikan referensi tidak terbatas pada karya yang berbahasa Indonesia, namun juga merambah ke sumber yang berbahasa Arab dan Inggris, sebagian lagi merujuk pada karya terjemahan yang berasal dari bahasa Inggris. Tulisan yang dijadikan rujukan tidak terbatas pada buku, tetapi juga artikel jurnal, artikel majalah, bab buku, dan termasuk pula Disertasi doktoral. ${ }^{42}$

Tafsir at-Tanwir merujuk kepada karya yang berbahasa Arab sebanyak 24 karya. Tiga Belas di antaranya merupakan kitab-kitab tafsir berbahasa Arab yang dapat dideteksi melalui catatan kaki maupun daftar pustaka yaitu: (1). Tafsir Jami' al-Bayan 'an Ta'wil Ay al-Qur'an karya al-Thabari (w. 923 M); (2). Tafsir al-Kasyf karya al-Zamakhsyari (w. $1144 \mathrm{M}$ ); (3). Al-Muharrar al-Wajiz karya Ibn 'Athiyah (w. $1147 \mathrm{H}$ ); (4). Tafsir alQur'an al-Azhim karya Ibn Katsir (w. 1373 M); (5). Tafsir Rub al-Ma'ani karya al-Alusi (w. 1802 M); (6). Mabasin al-Ta'wil karya al-Qasimi (w. 1914 M); (7). Tafsir al-Manar karya Rasyid Ridha (w. 1935 M); (8). Tafsir al-Maraghi karya al-Maraghi (w. 1952 M); (9). Fi Zhilal al-Qur'an karya Sayyid Qutb (w. 1966 M); (10). Tafsir al-Tabrir wa al-Tanwir karya Ibn Asyur (w. 1973 M); (11). Tafsir al-Munir karya Wahbah al-Zuhaili (w. 2015); (12). Rawa'i al-Bayan fi Tafsir al-Ayat al-Abkam dan (13). Shafwat al-Tafasir, dua tafsir terakhir adalah karya yang pengarangnya masih hidup, Ali Al-Shabuni (lahir. $1930 \mathrm{M}){ }^{43}$

Deretan nama-nama tersebut menggambarkan dominasi tafsir-tafsir yang ditulis oleh para pemikir dan penggerak Moderasi Islam di Timur-Tengah abad 20 M, bahkan

40 Majelis Tarjih dan Tajdid Pimpinan Pusat Muhammadiyah, Tafsir al-Tanwir, 50-51.

${ }^{41}$ Majelis Tarjih dan Tajdid Pimpinan Pusat Muhammadiyah, Tafsir al-Tanwir, 58-64.

${ }^{42}$ Majelis Tarjih dan Tajdid Pimpinan Pusat Muhammadiyah, Tafsir al-Tanwir, 485-489.

${ }^{43}$ Majelis Tarjih dan Tajdid Pimpinan Pusat Muhammadiyah, Tafsir al-Tanwir, 485-489. 
ada mufasir abad ke $21 \mathrm{M}$ yang dirujuk, yakni Wahbah al-Zuhaili ${ }^{44}$ dan Ali al-Shabuni. ${ }^{45}$ Barangkali terjadi penyegaran pemikiran dalam internal tokoh Muhammadiyah sehingga merujuk pada dua nama tokoh terakhir. Sementara nama-nama yang sudah tidak asing lagi bagi kalangan reformis Muhammadiyah juga masih tetap dicantumkan, Rasyid Ridha, Sayyid Quthb, dan al-Maraghi. Kendati demikian, mereka tidak mengabaikan mufasir legendaris seperti, al-Thabari dan Ibn Katsir sebagai bagian dari mufasir riwayah beraliran Sunni dan al-Zamakhsyari dengan tafsirnya yang ra'yi beraliran Mu'tazilah.

Tidak ketinggalan, Tafsir at-Tanwir turut merujuk tafsir-tafsir produk dalam negeri, seperti Tafsir al-Azhar karya Hamka, tentu karena se-visi dengan ideologi Muhammadiyah. Namun sayangnya tim penulis menganak-tirikan Tafsir al-Nur karya Hasbi al-Shiddieqy dan Tafsir Sinar karya Abdul Malik Ahmad. Padahal dalam testimoni kata pengantar Tafsir at-Tanwir, dua nama tafsir ini juga disebut sebagai perintis tafsir Muhammadiyah. Terlalu klasik bila tetap memahami Muhammadiyah hari ini sama dengan kemaren lampau. Buktinya, Tafsir at-Tanwir juga tidak menafikkan Tafsir alMishbah dan Wawasan al-Qur'an karya Quraish Shihab dan al-Qur'an dan Tafsir yang disusun oleh Tim Kementerian Agama. Benarkah telah terjadi pergeseran di Muhammadiyah ke arah keterbukaan?

Tafsir at-Tanwir termasuk tafsir yang berani keluar dari pakem. Tafsir ini berani merujuk tulisan berbahasa Inggris sebanyak 17 karya atau sebanyak 26\%, misalnya tulisan: Peter Scoot Adamson (lahir. 1972) seorang pakar filsafat di Amerika; Sosiolog Peter Ludwig Berger (w. 2017); pakar kitab suci, Maurice Bucaille (w. 1998); pakar medis dan kesehatan Erminia Guarneri (lahir, 1959), seorang penggagas Islamisasi ilmu Ismail Raji al-Faruqi (w. 1986), begitu pula tulisan Michael H Hart (lahir. 1932), C.T.R. Hayward (lahir. 1948), Hartwig Hirschfeld (w. 1934) dan lainnya. ${ }^{46}$ Namun, usaha ini masih belum maksimal. Sebab, terdapat 7 karya terjemahan dari bahasa Inggris yang dirujuk, bukan langsung merujuk karya asli. Tetapi tidak terlalu buruk, untuk sebuah pandangan Islam Berkemajuan.

Selain menggunakan sumber-sumber berbahasa Arab, Inggris, dan buku terjemahan, Tafsir at-Tanwir tetap merujuk karya-karya cendikiawan Indonesia terkenal, seperti karya Said Agil Husin al-Munawwar dan Abdul Halim, Fikih Haji Menuntun Jamaah Mencapai Haji Mabrur, (Jakarta: Ciputat Press, 2003), Nurcholis Madjid, "The Islmaic Concept of Man and Its Implications for Muslim Apprecation of The Civilan Political Rights", al-Jami'ah, No.65/VI/2000, termasuk juga karya Muhammad Quraish Shihab, Membumikan al-Qur'an, (Bandung: Mizan, 1993). Disamping karya dua karya tafsirnya yang telah disebutkan sebelumnya dan karya-karya lainnya.

Bagian yang tidak dapat disangkal adalah Tafsir at-Tanwir masih mengadopsi dan berorientasi pemikiran ideologis Muhammadiyah. Tafsir ini mengutip, Himpunan Putusan Tarjih (2011), Manbaj Gerakan Mubammadiyah (2009), dan Tanya Jawab Agama (1998) yang masing-masing ditulis oleh Tim PP Muhammadiyah. Bias pemikiran keMuhammadiyah-an juga dirasakan ketika dua nama yang tergabung dalam Tim Penulis tafsir yang juga tokoh Muhammadiyah turut dirujuk. Dua nama tersebut adalah

\footnotetext{
${ }^{44}$ Wahbah al-Zuhaili (w. 2015) merupakan seorang ulama dan peneliti di Suriah, ia lahir di Dair Athiyah tahun 1932. Ia merupakan lulusan Fakultas Syariah Damaskus dan doktoral di Fakultas Syariah Universitas al-Azhar Mesir. Kemudian diangkat menjadi dosen dan akhirnya menjadi dekan di Fakultas Syariah Damaskus. Bidang kepakarannya fiqih, tafsir, dan pemikiran Islam. Anshori, Menafsirkan al-Qur'an dengan Ijtihad, (Jakarta: Referensi, 2012), 142-143.

${ }^{45}$ Ali al-Shabuni lahir di Syiria, tepatnya di Halb Syu'ba tahun1930. Ia merupakan seorang pemikir yang produktif terutama di bidang tafsir al-Qur'an. Ia mendapatkan gelar profesor di bidang syariah dan dirasah islamiyah (Islamic Studies) di Universitas King Abdul Aziz Mekkah. Muhammad Yusuf, Studi Kitab Tafsir Kontemporer, (Yogyakarta: Teras, 2006), 49.

${ }^{46}$ Majelis Tarjih dan Tajdid Pimpinan Pusat Muhammadiyah, Tafsir al-Tanwir, 485-489.
} 
Muhammad Chirzin, seorang Guru Besar Tafsir al-Qur'an UIN Sunan Kalijaga Yogyakarta dan seorang lagi Hamim Ilyas yang juga merupakan dosen di Universitas yang sama dengan Chirzin. Muhammad Chirzin merujuk tulisannya sendiri berjudul: Kearifan al-Qur'an: Rahasia Mengapa al-Qur'an Tak Lekang Waktu, Jakarta: Gramedia, 2011) sewaktu menafsirkan surah al-Baqarah 23-24. Sementara tulisan Hamim Ilyas berjudul: “Islam Rahmatan Lil'alamin: Penjabaran Islam Sejati dalam al-Qur'an”, dalam Hamim Ilyas, dkk, Hamonisasi Umat Beragama, (Yogyakarta: Arti Bumi Intaran, 2012). Dirujuk oleh Tim Penulis (Muhammad Amin, Ustadi Hamzah, Siti Aisyiah, Aly Aulia, dan Moh. Dizkron) ketika menafsirkan surah al-Fatihah 1-7.

\section{Persentase Rujukan Tafsir at-Tanwir Muhammadiyah dari Aspek}

Bahasa

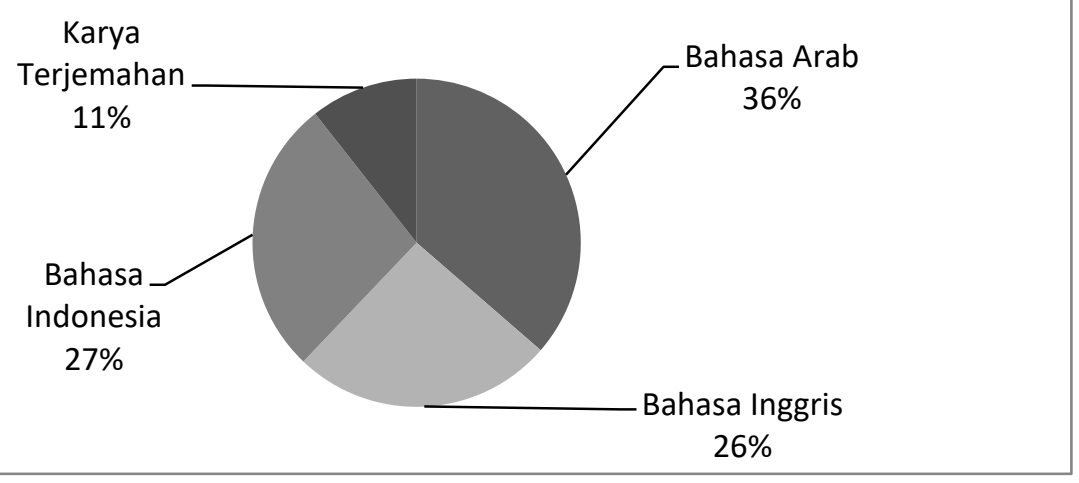

\section{Simpulan}

Belakang layar Tafsir at-Tanwir (2015) yang disusun oleh Tim Tarjih dan Tajdid PP Muhammadiyah merupakan orang-orang yang berkiprah di dunia kampus. Semuanya merupakan aktifis sekaligus akademisi tulen Muhammadiyah, bahkan separuh (50\%) di antaranya merupakan Guru Besar alias profesor di Perguruan Tinggi Negeri maupun Swasta. Selebihnya 4 orang atau 29\% merupakan lulusan Strata Tiga (S3) dan Strata Dua (S2) 21\% atau sebanyak 3 orang. Wajar bila menggelari tafsir ini dengan sebutan "Tafsir Akademis" Dari 14 orang penafsir yang tergabung dalam tim, terdapat seorang mufasir wanita, Dra. Siti Aisyah, M.Ag. Meski hanya berbobot $7 \%$ bila dibanding dengan mufasir laki-laki. Keterlibatan tersebut menunjukkan upaya kesetaraan gender dalam penulisan tafsir, satu fenomena langka di tanah air. Sedangkan kinerja penafsiran tidak bagi rata, sebagian kecil (16\%) digarap secara berkelompok, semantara (84\%) dikerjakan oleh mufasir individu, umumnya adalah para Profesor, hanya Dr. Hamim Ilyas yang tidak, namun memperoleh perlakuan instimewa.

Selain itu, berkaitan dengan gagasan tafsir al-Qur'an berkemajuan, Tafsir at-Tanwir masih mengusung ideologi puritan Muhammadiyah meski terlihat lebih modern. Tafsir ini sengaja ditulis secara kolektif, mengingat belum ada tafsir Muhammadiyah yang ditulis demikian. Resposifitas menghadapi tantangan terkini, membangkitkan dinamika, dan menyisipkan nilai-nilai etos ke-Muhammadiyah-an sangat getol dinarasikan dalam tafsir ini. Ada empat etos Muhammadiyah yang digulirkan dalam tafsir ini, yakni: tentang etos ibadah, etos ekonomi, etos sosial, dan etos keilmuan. Nuansa empat etos ini begitu terasa, dalam tiap lembaran Tafsir at-Tanwir. Tafsir at-Tanwir dapat dibilang sebagai "Tafsir Sistematis" karena uraian sistematika dan teknik penulisan sangat tersusun, urut, dan tertata rapi. Secara teknis, tafsir ini tidak mengabaikan cara kerja tafsir klasik, seperti merujuk kepada al-Qur'an, hadits, pendekatan bahasa, perbedaan qira'at, munasabah, namun ia juga berupaya mengkombinasikan dengan perspektif lain, misalnya filsafat dan sains, tentu tidak ketinggalan tafsir ini mencatolkan dengan ideologi Muhammadiyah. Terkait dengan rujukan tafsir, Tafsir at-Tanwir telah berupaya keluar dari pakem, dengan merujuk literatur berbahasa 
Arab (36\%) dan Inggris (26\%), namun sayangnya masih merujuk ke buku terjemahan (11\%). Sebuah gebrakan luar biasa demi sebuah tafsir yang berkemajuan.

\section{Daftar Pustaka}

Abror, Indal, and Muhammad Nurdin Zuhdi. “Tafsir Al-Qur'an Berkemajuan: Exploring Methodological Contestation and Contextualization of Tafsir At-Tanwir by Tim Majelis Tarjih dan Tajdid PP Muhammadiyah." ESENSLA: Jurnal Ilmu-Ilmu Ushuluddin 19, no. 2 (October 23, 2018): 249-77. https://doi.org/10.14421/esensia.v19i2.1347.

Hidayat, Syamsul. "TAFSIR JAMA'I UNTUK PENCERAHAN UMMAT." Wabana Akademika: Jurnal Studi Islam Dan Sosial 4, no. 2 (January 2, 2018): 245-56. https://doi.org/10.21580/wa.v4i2.2079.

Jauhari, Indah Yuliani. "Neo-Sufisme Tafsir at-Tanwir QS.al-Fatihah (Karya Tim Penyusun Pimpinan Pusat Majlis Tarjih Dan Tajdid Muhammadiyah)." Undergraduate, UIN Sunan Ampel Surabaya, 2019. http://digilib.uinsby.ac.id/30287/.

Mubarak, Muhammad Syahrul. "KONTEKSTUALISASI SURAH AL- FATIHAH DALAM TAFSIR AT-TANWIR MUHAMMADIYAH.” UIN SUNAN KALIJAGA, 2017. http://digilib.uin-suka.ac.id/28442/.

MUHAMMAD RIDHA, NIM: 1620510004. "TAFSIR KELEMBAGAAN MUHAMMADIYAH (Studi Terhadap Tafsir Tematik Al-Qur an tentang Hubungan Sosial Antarumat Beragama dan Tafsir At-Tanwir)." Masters, UIN Sunan Kalijaga, 2018. http://digilib.uin-suka.ac.id/34019/.

Anwar, Rosihon (2015). Ulum al-Qur'an, Bandung: CV. Pustaka Setia.

Federspiel, Howard M. (1996). Kajian al-Qur'an di Indonesia: Dari Mabmud Yunus Hingga Quraish Shibab, Bandung: Penerbit Mizan.

Gusmian, Islah, (2013). Khazanah Tafsir Indonesia: Dari Hermeneutika Hingga Ideologi, Yogyakarta: Lkis.

Hamka, (2015). Tasawuf Modern. Jakarta: Republika Penerbit.

Kiptiyah, Siti Mariyatul, (2018). Tafsir Alquran Carakan: Nalar Mubammadiyah dalam Sejarah dan Literatur, Tesis Konsentrasi Hermeneutika al-Qur'an, Prodi Interdisciplinary Islamic Studies, Pascasarjana UIN Sunan Kalijaga Yogyakarta.

Muhammadiyah, (2015). Majelis Tarjih dan Tajdid Pimpinan Pusat. Tafsir al-Tanwir, Yogyakarta.

Shihab, M. Quraish. (2006). Tafsir al-Mishbab: Pesan, Kesan, dan Keserasian al-Qur'an, cet. V, Jakarta: Lentera Hati.

Subhan, Zaitunah, (2016). Tafsir Kebencian: Studi Bias Gender dalam Tafsir al-Qur'an, Yogyakarta: LKis Pelangi Aksara Yogyakarta.

www.kompasiana.com.

www.uin-suka.ac.id.

www.unisayogya.ac.id.

Yusuf, Muhammad, (2006). Studi Kitab Tafsir Kontemporer, Yogyakarta: Teras.

Zuhdi, M. Nurdin, (2014). Pasarraya Tafsir Indonesia: Dari Kontestasi Metodologi Hingga Kontekstualisasi, Yogyakarta: Kaukaba Dipantara. 